\title{
The traditional Afrikaans-speaking churches in dire straits
}

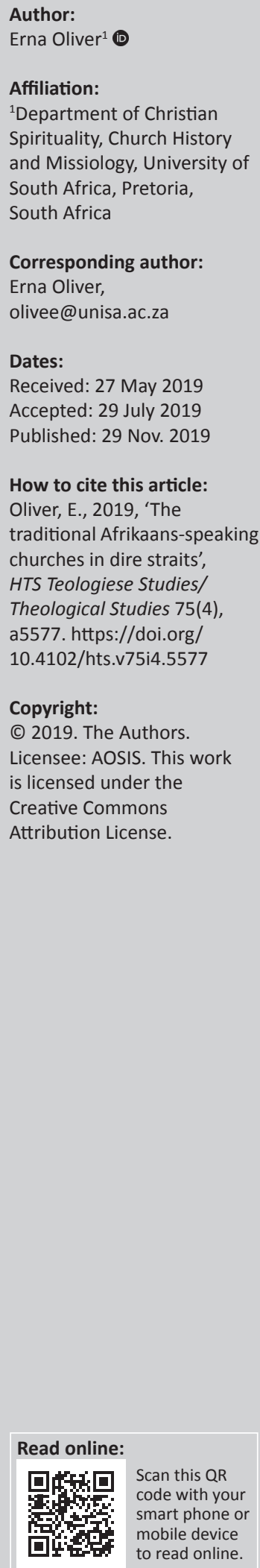

Christianity is entering another revolution or reformation phase. Five hundred years ago, Luther stood up against the Roman Catholic Church, which started the reformation and the reformed movement, culminating in the birth of the Reformed Churches (RC). Today these RCs are seemingly the victims of the new revolution. The traditional Afrikaans-speaking RCs in South Africa serve as a striking example. The symptoms of these churches correspond to those of a dying church, highlighted by scholars like Rainer, Noble, Niewhof and Mattera. Central to this situation is the fact that the relationship with God and his commandments is no longer the focus point of the churches. Thus, the identity crisis that the churches are experiencing is mirroring the chaotic South African society of violence, corruption and hopelessness. For these churches to turn the death spiral around, a reformation is needed that will transform them into alternative societies of peace and hope, founded on a living relationship with God. This article ends with suggestions on how to turn the tide for these churches, or at least how to start doing something positive to get out of the crisis.

Keywords: Afrikaans-Speaking churches; Death spiral; Dying church; Identity crisis; Reformation; South Africa; Christianity.

\section{Introduction}

Looking back at the history of Christianity, one can see the patterns of ebb and flow. Some scholars tag the global patterns of Christianity into 500-year cycles (De Klerk \& Van Helden 2011:2:10; Tickle 2012), implying that society is currently entering the fifth Christian revolutionary era. One outstanding characteristic of the current upheaval in the Christian religion is a dramatic shift to the Global South (Center for the Study of Global Christianity 2013:7). Faith is also becoming more prominent (Joubert 2018:1-7 refers to it as 'reality turned liquid') and un-institutionalised (Kok 2018:181). However, as the sad consequences of casualties and death are likewise inherent to the revolutionary process and turbulent times, it seems as if the traditional Reformed Churches (RCs) are the ones that are taking the hardest blows in the current transformation. Some scholars are questioning the survival of the traditional RCs worldwide (cf. Van der Merwe 2015:1) and predictions are that this type of faith will not prevail (Peterson 2013:1). However, similar to the previous revolutions experienced by Christianity, the traditional or old form and institution will probably not go totally extinct.

In Europe (Davie 2007:272) and North America (Bruce et al. 2006:111; Roozen 2008:5), church membership is drastically declining and numerous churches have already closed their doors permanently. In Europe, people are leaving the church in large numbers, mainly because of agnosticism and atheism, while in North America there is a significant rise in the number of unaffiliated people, both religious and non-religious (Center for the Study of Global Christianity 2013:7). Although Africa is experiencing growth and expansion of the Christian faith (mostly African Initiated Churches) and predictions point towards even greater things to come in the next few decades for Christianity on this continent, some RCs are in dire straits and sharing the symptoms of the terminally ill and dying churches in Europe and North America.

In South Africa, the three traditional Afrikaans-speaking churches ${ }^{1}$ and their conservative schismatic offspring ${ }^{2}$ are seemingly caught up in a 'death spiral' (Rainer 2017). While Rainer (2017) and others (Mattera 2018; Niewhof 2016; Noble 2016), who warn about dying churches (mostly in Northern America), are generally referring to single congregations or individual churches, the South African situation is worse because the future existence of denominations is at 1.These are the Dutch Reformed Church (DRC), the Nederduitsch Hervormde Kerk (NHC) and the Reformed Churches (RC)

2.The Afrikaanse Protestantse Kerk (APK) that spilt from the DRC in 1987 took 30287 members with them, while the Geloofsbond van Hervomde Gemeentes (GHG) that split from the NHC in 2013 took 6862 members with them. 
stake. Since the mid-1980s, these churches started to experience symptoms of decay and regression as the reality of cognitive dissonance ${ }^{3}$ started to take hold (about the fact that the churches actively supported the government during the apartheid era and, by doing so, became the handmaid of politics and ideology while discarding the calling to provide an alternative society to the diverse and unequal South African population) and disillusioned people started to question not only the relationship between church and state (Wepener 2015) but also other issues that the postmodern culture shifts brought to the table. Rossouw (1993:894-907) indicates some of the major challenges that Christianity should have addressed to successfully adapt to the postmodern era. Among other things, he asks for critical selfreflection (Rossouw 1993:897), active involvement in moral discourses (Rossouw 1993:898), a narrative theology (Rossouw 1993:899), a concern for the marginalised (Rossouw 1993:902) and a change from being right to doing what is right (Rossouw 1993:903). In line with these challenges and also in the 1990s, Backham (1995) in America calls for a similar reshaping of the church. He says that the church should be less isolated from the world, but not so much influenced by the world. The church must use its money and manpower positively and speak about the needs of the community, such as joblessness and poverty. The church must be less materialistic and less politically involved and must focus on people, not programmes (Backham 1995:26-27). More recently, in the post-postmodern era, Phiri (2017:2) called upon South African Christians to celebrate the gifts of the Spirit, to visit and attend to the wounds that were afflicted in the past and to actively transform injustice. Sadly, the failure to engage in adequate ways with these basic issues that should form part of the constant evolving identity of the church on the one hand, and the church-state relationship on the other hand, is activating a 'slow death' (Gilbert 2004:4-6) in churches, and recently Ungerer (2013) stated that the traditional Afrikaans-speaking churches are currently doing their own death counselling.

Being aware of the fact that the traditional Afrikaansspeaking churches are fighting for survival, Van der Merwe (2014) poses the question, 'why is the church doing what it is doing?' This gives the implication that the answer is not to proclaim the gospel through missional spirituality (Van der Merwe 2014:12) in accordance with the Great Commission ${ }^{4}$ and therefore the church has lost its identity and reason for existence. Hanekom (2014) agrees that the main reason for the shrinking church is the lack of a missional dimension which is perhaps the strength of Pentecostal Christianity. The church is no longer true to its calling and therefore not able to uphold its identity and existence. Just like Israel's religion got institutionalised and people no longer had a living relationship with God and a calling to change the world by

3. Festinger (1957) describes cognitive dissonance as the feeling of tension that most people experience when they recognise that they hold two 'cognitions' - ideas, beliefs or opinions - that contradict each other.

4.The mandate of the Great Commission as summarised by Kim (2013:262), includes the following four challenges: evangelistic, discipling, missional and global - a imbedded in the Lords' challenge for love (to God and all people - Mt 28:16-20). doing what God commands, the Afrikaans-speaking churches are practising a form of religion that was described during the apartheid era as heresy and currently as formalistic, outdated and dying.

Adding to the internal problems such as those listed above, the unique South African context further complicates the situation with factors like the need to adapt to the fourth industrial revolution world we are living in and adjusting to the political context and facing the consequences of the past. However, these are beyond the scope of this investigation.

This research compares the current state of the traditional Afrikaans-speaking churches with the key symptoms of dying churches, listed in several sources, to establish the current state and possible future of these churches. The information from several websites and publications was used to create a general list of common symptoms of dying churches against which the traditional Afrikaans-speaking churches can be measured (although not all of these listed items will be discussed in detail). The symptoms include, but are not limited to, a decline in the number of memberships and a monogenerational membership; infighting, conflict and blameshifting; a lack of effective leadership; financial woes; sacred cows; attitude issues such as resistance to change and personal growth and development; and a tendency to be reactive and not proactive. The focus of terminally ill churches is normally inward, on survival, maintenance and often also on the past. These churches normally lack a focus on missiology and service towards positive change in the community. The lived relationship with God, both by individuals and the congregation, is often not expressed in all activities, values, worldviews and words.

Determining the state of the traditional churches calls for suggestions and recommendations for the way forward.

The method of investigation followed in this study is document analysis, which is a qualitative social research method in which documents are interpreted to give voice and meaning on a specific topic (Bowen 2009:27).

\section{Signs of a dying church}

The checklist below is constructed from various sources (Mattera 2018; Niewhof 2015, 2016; Noble 2016; Rainer 2011; 2016; 2017; 2018; Whitter 2019) to identify some major symptoms of dying churches (Table 1). In general, most congregations of the three traditional Afrikaans-speaking churches can tick or display a majority of these symptoms.

\section{The traditional Afrikaans-speaking churches' survival crisis}

By the end of the 20th century, there were approximately 5793 Christian denominations in South Africa, of which 185 were from the Reformed tradition (Johnstone \& Mandryk 2001:511). Contributing to this large number of Reformed denominations are the Afrikaans-speaking churches. Before 
Numerical decline for 4 or more years.

The congregation or church is mono-generational, mostly senior adults.

The focus is mainly on keeping people and not on winning people for Christ.

Blame-shifting and excuses are used for the way things are.

The budget and everything else are inwardly focused and the church and/or congregation is in preservation mode.

Talks are more focused on the past than on the future.

Every service is predictable.

Regarding leadership:

- no new or young or innovative or different leaders (e.g. women or marginalised people) in decision-making positions

- positions, titles and status are very important

- management often replaces leadership

- leadership is not in line with the 'priesthood of all believers' principle.

Conflict often centres on issues of

- money

- worship style and time

- use of facilities.

Not focused on the needs of the younger generation.

Not focused on the needs of the community in which the church or congregation functions.

Resistance to change or innovation.

No or small budget for core work (e.g. missionary work).

\section{Identity issues}

The relationship with God has gone flat.

The Bible is not central (in South Africa it is often replaced with tradition or the 'ownership of the truth' syndrome).

Corporate prayer is not a major focus or activity.

The church or congregation has more meetings than new members.

No passion or urgency for evangelism or fulfilling the Great Commission.

Limited space for or focus on spirituality.

No process of discipleship; just a plethora of programmes and activities.

Voicelessness.

Other

Urgency about the wrong things (like money, buildings and survival).

The goal is to maintain, and not to make wrinkles; no or few steps of faith.

Growth is transfer growth.

Concerned about music style, programmes, schedules, facilities; not proclaiming the gospel.

speaking about the drastic decrease in the number of memberships of these traditional churches, as a major symptom of the current crisis, a short note is needed to explain the fact that there still exists three ${ }^{5}$ churches (actually more, if the 20th-century schismatic offspring of these churches - the Afrikaanse Protestantse Kerk [APK] and Geloofsbond - are included) with the same confessional, cultural and language foundations. A canonising of the past, differing Bible interpretations, doctrinal disputes and general stubbornness (Oliver 2019:3-7), resulted in the development of three Afrikaans-speaking RCs within a decade or two after the Great Trek. The success of the first Anglo-Boer War stimulated a feeling of unity and some Afrikaners tried to establish unity between the churches. Two of the three churches briefly united between 1885 and 1892, after which they again went their own ways. In 1939, a few months before the onset of the Second World War, an inter-church commission was established to once again try to bring the churches together. Over the years, this commission changed its name twice (it is currently known as the Inter-Church Council) and it never succeeded to establish unity between the 'sister' churches. During the and Spoelstra (1963) on the RC. last decade of the 20th century, the council concluded that it is 'not realistic' to keep pushing for unity between the churches and the focus shifted from unity to cooperation (Gereformeerde Kerke 2009:154).

It must be emphasised that all these churches (including those that split from them) in general confess on unity in faith through the Confession of Nicaea (Oliver 2011:40), but also see their form of religion and themselves as the sole keepers of the truth (Oliver 2007:34) without experiencing any form of cognitive dissonance about these controversies. The fruitless efforts to establish unity for more than a century proved how difficult it is to change the perceptions of people who choose to believe their own interpretation of events and dogma (cf. MacMillan 2009:87). The Afrikaans-speaking churches are using the term 'cooperation' as an evasive action to avoid, block, ignore and deny cognitive dissonance (Travis \& Aronson 2008) and to camouflage heresy and schism. Although schism does not generally appear in the lists of symptoms of dying churches, in the South African context, this refusal to unite because of the 'owners of the truth-syndrome' that most Afrikaner Christians suffer from (Oliver 2007:34) will most probably be contributing several nails to these churches' coffins. 
The lists, however, mention infighting, conflict and blameshifting, which are all related to schism. Steyn (2006:661-676) identified at least five major movements within the Dutch Reformed Church (DRC), which are causing power and status struggles, personal vendettas and intolerance. This identity crisis ${ }^{6}$ within the churches (cf. Steyn 2005:551 on the DRC) started in the mid-1980s when apartheid theology started to crumble, while the consequential losses in credibility, status and power for the institutions and church leaders resulted in such trauma that these churches and leaders became lame and mute, paralysing the churches to such an extent that they have lost their voice and ability to act positively (Steyn 2005:551). The churches are currently still acting as if they are deaf and blind - unable or unwilling to assist and support those in need on the one hand, or only focusing inward on the needs of its existing members on the other hand. There are no actions and protests, prophecy and provision of alternatives to the corruption, crime and other evils that are crippling the South African society. When there is a rare flickering of life (like when a church tries to update its rules and regulations, e.g., the position of marginalised groups - again an inward action), it often acts in such a way that people feel even more offended, and more members ${ }^{7}$ are actively exiting the church either to become un-churched believers or to join more progressive forms of Christianity and Spirituality. Interestingly, the issues listed by the Moreleta Park congregation of the DRC that made them want to leave are similar to those identified as problem areas in the lists above, namely, that God must be first in everything; Christians should operate in unity; leaders must stand up for the truth and have courage to stay with what is right; Christians must ensure that they have a personal relationship with God; and the congregation must adhere to their evangelical or missional calling to all people (Strydom 2019).

Closely linked with the infighting and power struggles is the lack of competent spiritual leadership. Often churches and congregations are 'managed' through the dependency model that leaves no space for the priesthood of all believers to be active agents of positive change. Even in the 21st century, these churches are clinging to hierarchical systems, dependency models and male dominance paradigms (cf. Oosthuizen 2018:43; 205). The recent work of Oosthuizen (2018:167 139) refers to 'Bible bullies' and 'church bullies' whose actions and words are still causing self-destruction and further schisms within the institutions. The lack of true spiritual leadership diverts the focus from what is really important - namely, putting the glory of God first, obey and live the Great commandment and to provide an alternative society built upon prayer and a personal relationship with God - to focus on popularity contests, worship styles and the use of facilities.

6.An identity crisis is a psychosocial state or condition of disorientation and role confusion. It is the result of conflicting experiences, pressures and expectations and often goes hand in hand with an acute display of emotions (The Free Dictionary 2019).

7.Even congregations are lately trying to leave the DRC: The Moreleta Park congregation, the largest congregation of the DRC with about 14000 members, congregation, the largest congregation of the DRC with about 14000 members,
recently ( 02 May 2019) indicated that they want to leave the institution, but after a recently (02 May 2019) indicated that they want to leave the institution, but after
meeting with the church leaders they decided not to leave yet (Strydom 2019).
TABLE 2: Number of membership of the three traditional Afrikaans-speaking churches in South Africa from 1985 to 2018.

\begin{tabular}{lll}
\hline Church & $\mathbf{1 9 8 5}$ & $\mathbf{2 0 1 8}$ \\
\hline RC & 116117 (Almanak GKSA 1986:288) & $87747 \dagger$ (Du Plessis 2018) \\
NHC & 194197 (Dreyer 1986:126) & 84864 (Breedt 2018) \\
DRC & 1431906 (Jaarboek NGK 1986:42) & 900267 (Van der Merwe 2019) \\
\hline
\end{tabular}

NHC, Nederduitsch Hervormde Kerk; RC, Reformed Churches; DRC, Dutch Reformed Church $\dagger$, Since 2010, these numbers also include members from all races.

One of the most noticeable symptoms of a dying church is a consistent fall in the number of memberships for 4 or more consecutive years (Rainer 2017). In South Africa, the decline of the number of memberships of the traditional Afrikaansspeaking churches started in the mid-1980s and has not yet stopped (Table 2).

Stats SA indicates that in 1985 , more than $5 \%$ of the population of South Africa were members of the three traditional Afrikaans-speaking churches. By 2018, this number dropped to about half a per cent ${ }^{8}$ of the population (Stats SA 2018). The DRC, the largest of the three denominations, lost more than half a million members (531 639 ) over the last 30 years, amounting to $37 \%$. The NHC lost more than $56 \%$ of its membership in the last three decades and the RC, traditionally the smallest of the three churches, is currently the second largest despite also losing about $24 \%$ of its members.

In reality, the picture is even darker than what is presented through the statistics listed above. A large number of people are still officially members of these churches but are not actively involved in any church activities (absentees and passive members) or even part of the fast-growing unchurched $^{9}$ group (cf. Oosthuizen 2018:202). What is left is in many cases, mostly senior adults (cf. Oliver 2006:118), contributing to the mono-generational character of the churches (Schoeman 2014:4). Less than 34\% congregants regularly attend church services (Barnard 2019). The alarm about these dwindling numbers is sounding since the 1990s, but it seems as if denying and underestimating ${ }^{10}$ the real graveness of the declining numbers is even currently at the order of the day and the issue is greatly ignored because of ascribing the phenomenon to a list of cover-up and superficial reasons.

Apart from emigration (about 1545098 white South Africans emigrated between 1986 and 2015 [Stats SA 2015]), ${ }^{11}$ the decline in the birth rate (Dreyer 2003:1054) and a loss to charismatic churches, the influence of the materialistic postmodern world we live in (De Klerk \& Van Helden 2011:3-10) is usually listed as the main reason for the decline.

8.This half a percentage point includes the APK and the GHG members.

9.'Unchurched' means, in the broad sense, people who are Christians but are not connected to a church or congregation and do not attend worship services.

10.Andre Bartlett, the moderator of the Highveld synod, recently said that the DRC is 'so bietjie besig om agteruit te boer' [going backwards a little bit] (Prins 2018:16).

11. Neither the Department of Home Affairs nor the International Relations Department keeps records of people emigrating from South Africa. Therefore, the most recent numbers are from the Stats SA 2016 community survey that estimated that 97460 people emigrated between 2006 and 2006 (Africa Check 2019). 
The political situation in South Africa and the dismissal of apartheid are often listed as reasons for the declining numbers of the DRC, but Oosthuizen (2018:188) is correct in pointing out that if this was the case, the conservative schismatic churches would have grown substantially.

In line with the blame-shifting tendency of dying churches, the reasons given for the declining numbers do not include a lack of confession about malpractices (including heresy and schism) by the institutions, leadership (cf. Oosthuizen 2018:135) and members, or a confession about the church losing its alternative social identity and changing into a mirror of the broken and corrupt South African society.

In light of what is said above, the conclusion that Whitley (1969) has drawn about Christian churches in North America more than 40 years ago is true about the Afrikaans-speaking churches today: the church is becoming a mirror of society. It is no longer a window of hope in a hurting and chaotic society, providing an alternative space of shelter and peace. Churches are looking and acting like the world (Buitendag 2008:129) by sanctioning the values and norms emphasised by society (Whitley 1969:14). As a social and personal force, the Christian religion of the Afrikaners became a dependent variable: it no longer originates, it reacts.

It does not denounce, it adapts. It no longer sets forth new modes of conduct and sensibility; it imitates society (cf. Mills 1958:166). So, if there is no difference between life inside and outside the church, why does the church still exist? The church no longer offers an alternative space where the relationship with God and his word provides peace and salvation. The church as an institution became obsolete and disposable.

\section{The way forward}

The Christian faith will not fade or vanish in South Africa because of the terminally ill state that the traditional Afrikaans-speaking churches are finding themselves in, but the current institutional packaging (at least) of the Afrikaansspeaking traditional denominations must be discarded and replaced with a flowing, more liquid form (Schoeman 2014:10) and structure. Unfortunately, the church became so intertwined with the institutional sacred cows (such as leadership, owners of the truth syndrome and so on) that the substantial change that is required not only caused an identity crisis, but also sent the churches to their deathbed. Steyn is correct to side with Meiring (1980:207-215) in warning against cosmetic changes when open-heart surgery is required to save the life of the Afrikaans-speaking churches. Intense reformation is needed, but to the institutionalised 'sister' churches, it seems as if too much is at stake as the postponement of drastic reform is putting these churches on their deathbeds (cf. Rainer 2015).

Even if the current form of church (institution) is no more, this will not mean that Christianity died in the hearts and lives of South Africans. It will mean that God is showing a new way. Just like in nature, death often creates new life (the transformation of a worm into a butterfly or a seed into a plant) and maybe the traditional form and structure of the Afrikaans-speaking churches must die in order for something new to be created and developed into the next phase of Christianity (Kok 2018:178). The church must recover (discover) its identity through the imperative lens of metamemories from salvation history (cf. Volf 2006).

A positive way forward towards change and recovery will probably not come from the current church leadership (just like in the time of Jesus and the time of Luther), as the church leaders are hanging on to their positions and/or pension packages. It is time for Christians to take up their calling as priests (the priesthood of all believers) and to think and work towards 'the universal family of God more than that of their own parochial territories' (Kim 2013:262). Christians need to be united in oneness of faith, ministry and purpose.

Maybe like in the early centuries, at the hand of unrest, persecution and bullying, together with current institutional decay and neglect, Christians will find a way to grow and flourish and bring healing to our country. Aid, development and charity work that made these churches so strong after the Anglo-Boer War and up until the 1980s must once again flourish, this time not only focusing on designated groups, but also on the needs of South Africa in each community and nationally. In addition, the voice of the church must be heard, commenting on and guiding people to act according to their faith and to commit to create an alternative Christian society.

Firstly, cognitive dissonance must be used to make church members and leaders aware of why (the real reasons) the symptoms of terminal sickness are cancerating the institutions, their faith and relationship with God. Secondly, church members must receive death counselling to make peace with the fact that the church in its current state can no longer serve the people of this country, and start working towards constructing a different and new kind of faith community. Thirdly, the creative minds of people who are capable of designing and creating solutions to all kinds of problems (like all the patents that South Africans create) must design a new African Christian theology. People from all the different denominations must work together to create and develop a unique African, contextual theology with a missiological core built upon and around the Great Commission to serve the country and its people in our unique situation and circumstances in obedience to and within a living relationship to God.

The new creation and motion will probably not come from church leaders as they are too concerned about their status, pension and influence in society, while their feet of clay (to give in to corruption, discrimination, lack of determination to stand up for the truth, speak out against what is wrong in church, society, economy and government) will prevent them from taking such steps. Just like in the early church and during the later revolutions, it will be the marginalised and the outcasts who will bring reform, despite the restrains put onto them by laws, structures and hierarchical leadership. 
TABLE 3: A checklist for change, renewal and reform towards an African theology.

\section{Action}

\section{Stop doing this}

Thinking about faith as a safe and uncontested space.

Doing the same things and expecting different results.

Trying to get people to the church.

Seeking approval from society and/or the government.

Worrying about the institution and buildings and facilities.

Look for solutions to African problems in non-African contexts.

Start doing this

Put God first - always and in everything.

Take risks - live in faith.

Keep asking difficult questions.

Understand that unity in Christ means just that

Stay focused on the goal/mission/purpose as seen from God's side.

Think and act in a positive way - always.

Learn from history, learn from mistakes (yours and that of others).

Remember that faith changes people, not institutions.

Value the process of transformation, not only the end result.

Actively create an alternative society.

Create a holistic understanding of mission, including a social responsibility.

The current situation is opening opportunities for innovation at grass-roots level. Afrikaners are innovative (see all the South African designed patents). What can be created to take the place of the dying church? What can be formed that can be a constructive way of living Christian faith as it is intended on the African continent in the 21st century? There are already examples of grass-root projects such as the ekerk [e-church], urban ministries, numerous other projects and spiritual awakenings, but these projects and movements need to gather momentum to evolve and take the place of the dying churches in society (Table 3 ).

\section{Conclusion}

The traditional Afrikaans-speaking churches are in dire straits. The numbers of memberships are dwindling since the mid-1980s and hiding behind excuses while not trying to uncover the real reason for this, which is contributing to the critical state that these denominations are finding themselves in. Although numbers are a significant indicator that something is seriously wrong, there are also other symptoms that confirm the critical state of these churches. Most important is the identity crisis that is causing confusion, supported by the lack of spiritual leadership, the denial of the concept of the priesthood of all believers and a number of practical dilemmas. If these churches would consider changing their identity (from Afrikaans-speaking to inclusiveness in the diverse contexts of the country), there could be some hope for survival and even a thriving new Christian reformation in South Africa.

Unfortunately, similar to the previous revolutions (such as in the time of Jesus and again during the time of Luther), the institutional church became lifeless and stagnant. Living, changing, radical faith no longer resembles a relationship with the living God. In the light of the history of South Africa where apartheid actually crossed out the right to exist for the Afrikaans-speaking churches (Oosthuizen
2018:199), it is high time for the old structures, hierarchy, customs and dogma to make way for a renewal on the one hand, and for pacified members to be awakened to a new reformation on the other hand; something new and different must be created to carry the salvation in Christ to the broken world and especially to the violent, crime-ridden, corrupt South African society.

\section{Acknowledgements Competing interests}

The author declares that they have no financial or personal relationships which may have inappropriately influenced them in writing this article.

\section{Author's contributions}

E.O. is the sole author of this article.

\section{Ethical considerations}

This article followed all ethical standards for a research without direct contact with human or animal subjects.

\section{Funding information}

This research received no specific grant from any funding agency in the public, commercial or not-for-profit sectors.

\section{Data availability statement}

Data sharing is not applicable to this article as no new data were created or analysed in this study.

\section{Disclaimer}

The views and opinions expressed in this article are those of the author and do not necessarily reflect the official policy or position of any affiliated agency of the author.

\section{References}

Africa Check., 2019, 'South Africa's emigration problem - No one knows how big the brain drain really is', Businesstech, viewed 08 July 2019, from https://businesstech. $\mathrm{co} . z a /$ news/lifestyle/318736/south-africas-emigration-problem-no-one-knowshow-big-the-brain-drain-really-is/

Almanak, G.K.S.A., 1986, Die Almanak van die Gereformeerde Kerke in Suid-Afrika vir die jaar 1986, Jaargang 12, Administratiewe Buro, Potchefstroom.

Backham, W.A., 1995, The second reformation: Reshaping the church for the 21st century, Touch Publications, Houston, TX.

Barnard, M., 2019, 'NG Kerk se lidmate daal met 24,8\%', Beeld, 26 January 2019, viewed 10 May 2019, from https://www.pressreader.com/south-africa/ beeld/20190126/281509342402759.

Bowen, G.A., 2009, 'Document analysis as a qualitative research method', Qualitative Research Journal 9(2), 27-40. https://doi.org/10.3316/QRJ0902027

Breedt, K., 2018, email, 12 October, Karen@nhk.co.za.

Bruce, D., Woolever, C., Wulff, K. \& Smith-Williams, E., 2006, 'Fast-growing churches: What distinguishes them from others?', Journal of Beliefs and Values 27(1) 111-126. https:// doi.org/10.1080/13617670600594582

Buitendag, J., 2008, 'Ecclesia reformata semper reformanda - die ongemaklike eis', HTS Theological Studies/Teologiese Studies 64(1), 123-138. https://doi. org/10.4102/hts.v64i1.7

Center for the Study of Global Christianity, 2013, Christianity in its global context, 1970-2020. Society, religion and mission, Gordon Conwell Theological Seminary South Hamilton, viewed 06 May 2019, from https://www.gordonconwell.edu/ ockenga/research/.../ChristianityinitsGlobalContext.pdf.

Davie, G., 2007, 'Religion in Europe in the 21 century: The factors to take into account', European Journal of Sociology 47(2), 271-296. https://doi.org/10.1017)
S0003975606000099 
De Klerk, B.H. \& Van Helden, P., 2011, 'Oorsake van kerkkrimping binne die tradisionee Afrikaanssprekende gereformeerde kerke in SuidAfrika', Verbum et Ecclesia 32(1) Art. \#477, 10 pages. https://doi.org/10.4102/ve.v32i1.477

Dreyer, P.S. (ed.), 1986, Almanak en Bybelse dagboek, Guttenberg Drukkers, Pretoria.

Dreyer, T.F.J., 2003, 'Statistieke vertel 'n storie: ' $n$ Visie vir die Hervormde Kerk op pad na 2010', HTS Teologiese Studies/Theological Studies 59(4), 1045-1062. https:// doi.org/10.4102/hts.v59i4.685

Du Plessis, W., 2018, email, 09 October, wymiedup@gksa.co.za.

Festinger, L., 1957, A theory of cognitive dissonance, Stanford University Press, Stanford, CA.

Gereformeerde Kerke, 2009, Algemene Sinode 2009, Notule van die rapport deputate ekumenisiteit, Administratiewe Buro, Potchefstroom.

Gilbert, D.E., 2004, “"Deep change" or "slow death?" A practical road guide for the highway of change: A learning manual for church boards', PhD thesis, Faculty of Theology, Western Theological Seminary.

Hanekom, B., 2014, Getalle, gemeentes en gebed, viewed 08 January 2019, from http s://192.185.30.195/ kerkbode/getalle-gemeentes-en-gebed/.

Jaarboek, N.G.K., 1986, Jaarboek van die NG Kerk, Jaargang 137, Tydskrifmaatskappy, Kaapstad.

Johnstone, P.J.St.G. \& Mandryk, J., 2001, Operation world, Gabriel Resources, Donnelley, VA.

Joubert, S., 2018, “Flowing” under the radar in a multifaceted liquid reality: The ekerk narrative', HTS Teologiese Studies/Theological Studies 74(3), 7 pages. https://doi. narrative', HTS Teologiese Studi
org/10.4102/hts.v74i3.4966

Kim, S.-B.D., 2013, 'Changes and trends in world Christianity', Transformation 30(4), 257-266. Special issue: The Global Christian Forum: Life together in Jesus Christ, empowered by the Holy Spirit, viewed 03 May 2019, from https://www.jstor.org/ stable/10.2307/90008183.

Kok, K., 2018, Ja vir God, nee vir die kerk?, Carpe Diem, Vanderbijlpark.

MacMillan, M., 2009, The use and abuse of history, Profile Books, London.

Mattera, J., 2018, 13 signs of a dying church, viewed 08 October 2018, from https:// josephmattera.org/13-signs-of-a-dying-church/

Meiring, P., 1980, 'Eksklusief of Ekumenies?', in E. Botha, D. Steenberg, J. Taljaart, B. Van der Walt \& K. Van der Walt (eds.), Venster op die kerk. 20 lidmate oor die B. Veformasie van die kerk in die jare 80, pp. 207-215, Instituut vir Reformatoriese
refie reformasie van die kerk
studies, Potchefstroom.

Mills, C.W., 1958, The causes of World War three, Simon and Schuster, New York, NY.

Niewhof, C., 2015, 11 signs your church is going extinct, viewed 07 October 2018, from https://careynieuwhof.com/11-signs-your-church-is-going-extinct/.

Niewhof, C., 2016, 7 subtle signs your church is dying, viewed 07 October 2018, from https://careynieuwhof.com/7-subtle-signs-church-dying/

Noble, P., 2016, Signs of a dying church -15 signs your church is in trouble, viewed 07 October 2018, from https://churchleaders.com/pastors/pastor-blogs/138516-15_ signs_that_a_church.html.

Oliver, E., 2006, 'Sunday school: Past and present', Studia Historiae Ecclesiasticae $32(1), 117-134$.

Oliver, E., 2007, 'Thoughts on writing Afrikaner church history', Studia Historiae Ecclesiasticae 33(1), 23-40.

Oliver, E., 2011, 'The history of Afrikaans speaking churches in South Africa and the option of ecumenism', Studia Historiae Ecclesiasticae 37(1), 39-57.

Oliver, E., 2019, 'Religious Afrikaners, irreligious in conflicts', HTS Teologiese Studies/Theological Studies 75(1), a5204, 7 pages. https://doi.org/10.4102/hts. v75i1.5204

Oosthuizen, J., 2018, Die opkoms en ondergang van die NG kerk, Penquin Books, Cape Town.

Peterson, C.M., 2013, Who is the church? An ecclesiology for the twenty-first century, Fortress Press, Minneapolis, MN.

Phiri, I.A., 2017, 'Introduction', in E. Oliver (ed.), The reformation, transformation and change agency, pp. 1-5, AOSIS, Cape Town.

Pont, A.D., 1968, 'n Oorsig van die Algemene kerkgeskiedenis en die geskiedenis van die Nederduitsch Hervormde Kerk van Afrika, HAUM, Pretoria.
Prins, J., 2018, 'Kom ooreen om te verskil', Beeld, 03 November 2018, viewed 04 January 2019, from https://www.pressreader.com/south-africa/beeld/20181103/ 281487867355287.

Rainer, T.S., 2011, 10 signs a church is in trouble, viewed 07 October 2018, from https://pastors.com/10-signs-a-church-is-in-trouble/

Rainer, T.S., 2015, Anatomy of a sick church-10 symptoms to watch, viewed 20 May 2019, from https://thomrainer.com/2015/06/anatomy-of-a-sick-church-10-symptoms-towatch/

Rainer, T.S., 2016, Who moved my pulpit?: Leading change in the church, B\&H Publishing Group, Nashville, TN.

Rainer, T.S., 2017, Eight signs your church may be closing soon, viewed 07 October 2018, from https://thomrainer.com/2017/05/eight-signs-church-may-closing-soon/

Rainer, T.S., 2018, 8 warning signs of a dying church, viewed 08 October 2018, from https://churchjobfinder.com/8-warning-signs-dying-church/

Roozen, D.A., 2008, American congregations 2008, Hartford Institute for Religion Research, Hartford, CT.

Rossouw, G.J., 1993, 'Theology in a postmodern culture: Ten challenges', HTS Theological Studies/Teologiese Studies 49(4), 894-907. https://doi.org/10.4102/ hts.v49i4.2528

Schoeman, W.J., 2014, 'Agter die syfers is gelowiges, gemeentes en die kerk, n praktiese teologiese refleksie oor lidmaatskap', HTS Teologiese Studies/Theological Studies 70(1), Art \#2677, 10 pages. https://doi.org/10.4102/hts.v70i1.2677

Spoelstra, B., 1963, Die 'Doppers' in Suid-Afrika. 1760-1899, Nasionale Boekhandel, Johannesburg.

Stats SA, 2015, Mid-year population estimates, Department of Statistics, viewed 17 November 2015, from https://www.statssa.gov.za/publications/P0302/P03022015. pdf.

Stats SA, 2018, Mid-year population estimates, viewed 05 October 2018, from https:// www.statssa.gov.za/publications/P0302/P03022018.pdf.

Steyn, G.J., 2005, ‘Die NG Kerk se identiteitskrisis, Deel 1. Aanloop, terreine van beïnvloeding en reaksie', Nederduitse Gereformeerde Teologiese Tydskrif $46(3 \& 4)$ 550-559.

Steyn, G.J., 2006, 'Die NG Kerk se identiteitskrisis, Deel 2 huidige bewegings, tendense of mutasies', Nederduitse Gereformeerde Teologiese Tydskrif 47(3\&4), 661-676.

Strydom, N., 2019, Vergadering gehou oor Moreletapark se rol in NG Kerk, viewed 19 May 2019, from https://maroelamedia.co.za/nuus/sa-nuus/vergadering-gehouoor-moreletapark-se-rol-in-ng-kerk/

The Free Dictionary, 2019, Identity crisis, viewed 15 July 2018, from https://www. thefreedictionary.com/identity+crisis

Tickle, P.N., 2012, Emergence Christianity: What it is, where it is going, and why it matters, Baker Books, Grand Rapids, MI.

Travis, C. \& Aronson, E., 2008, Mistakes were made (but not by me): Why we justify foolish beliefs, bad decisions, and hurtful acts, Harvest Books, Orlando, FL.

Ungerer, A., 2013, Hoe lyk die kerk in ons wêreld?, viewed 12 January 2015, from https://www.hervormer.co.za/images/Mei\%202013.pdf.

Van der Merwe, J.C., 2014, 'n Narratief vir kerk-wees vandag', HTS Teologiese Studies/ Theological Studies 70(1), Art. \#2699, 13 pages. https://doi.org/10.4102/hts. v70i1.2699

Van der Merwe, J.C., 2015, 'Die inkarnering van die misso Dei as praktykmodel vir die Nederduitsch Hervormde Kerk van Afrika', HTS Teologiese Studies/Theological Studies 71(3), art. \#3066, 16 pages. https://doi.org/10.4102/hts.v71i3.3066

Van der Merwe, J.M., 2019, email, 08 January, johanvdm@intekom.co.za.

Van der Watt, P.B., 1987, Die Nederduitse Gereformeerde Kerk 1824-1975, NGK Boekhandel, Pretoria.

Volf, M., 2006, The end of memory: Remembering rightly in a violent world, Eerdmans, Grand Rapids, MI.

Wepener, C., 2015, Kookpunt! Nadenke oor woede: 'n Gelowige reaksie van 'n ontnugterde nasie, Biblecor, Wellington.

Whitley, O.R., 1969, The church: Mirror or window? Images of the church in American society, The Bethany Press, St Louis, MO.

Whitter, R., 2019, 6 subtle signs that a church is on its deathbed, viewed 07 October 2018, from https://www.crosswalk.com/church/pastors-or-leadership/6-subtlesigns-that-a-church-is-on-its-deathbed.html. 